\title{
Provenance and price: autoregulation of the antiquities market?
}

\author{
Neil Brodie \\ Scottish Centre for Crime \& Justice Research \\ School of Social and Political Sciences \\ University of Glasgow \\ Ivy Lodge, 63 Gibson Street \\ Glasgow G12 8LR \\ neil.brodie@glasgow.ac.uk
}

\section{Abstract}

It is becoming common to read that antiquities without a provenance stretching back to before the 1970 adoption by UNESCO of the Convention on the Means of Prohibiting and Preventing the Illicit Import, Export and Transfer of Ownership of Cultural Property are increasingly difficult to sell because of customer concerns over possible illicit trade in the past and reduced resale prices in the future. This paper proposes the term autoregulation to describe the phenomenon, and presents the results of several quantitative analyses designed to investigate its action.

Keywords

Antiquities trade; antiquities auctions; provenance; quality; regulation; autoregulation; 1970 UNESCO Convention.

\section{Introduction}

Antiquities are objects or parts of objects, including parts of buildings and monuments, that were made in ancient times - in antiquity. There has been an international and increasingly illicit trade in antiquities since the time of the eighteenth-century 'Grand Tour', most of which have been clandestinely excavated from archaeological sites or forcibly removed from architectural remains, to be acquired by private and institutional collectors worldwide. The trade has been blamed for damaging and destroying cultural heritage, thereby spoiling the raw material of historical research and degrading the economic substance of cultural tourism. Recent archaeological and art historical treatments of the subject include Brodie, Kersel, Luke and Tubb (2006), Rhodes (2007), Nafziger and Nicgorski (2009), Adler and Bruning (2012) and Lazrus and Barker (2012), and for criminology see Mackenzie (2005), Mackenzie and Green (2009), Tijhuis (2006) and Manacorda and 
Chappell (2011). The seriousness of the problem was recognised in 1970 by UNESCO when it adopted the Convention on the Means of Prohibiting and Preventing the Illicit Import, Export and Transfer of Ownership of Cultural Property, which recommended standards for national curation of cultural heritage and established a series of rules and diplomatic procedures aimed at controlling the trade, and which by June 2013 had been ratified by 123 countries (O'Keefe 2007; Forrest 2010: 166-196).

Argument over public policy as regards the trade has to a large extent focused upon the appropriateness and effectiveness of straightforward statutory regulation, by means of targeted trade controls (particularly within the diplomatic framework of the 1970 UNESCO Convention) and the enforcement of stolen property laws (applicable because of national patrimony laws, enacted by many countries to take cultural heritage into State ownership). The effectiveness of statutory regulation is perceived to have been uneven, in part because it is customary for antiquities to be traded with only incomplete provenance (ownership history) or even no provenance at all, so that on the market it is hard if not impossible to separate antiquities with a clean bill of health from those that have been illicitly-traded. Only recently, as the subject has started to attract the attention of criminologists, have the possibilities of a more flexible response been considered, inspired by Braithwaite's conception of a regulatory 'pyramid', where the punitive sanctions of criminal and civil law are reserved only for the most egregious cases of malpractice, with most of the work of discouraging wrongdoing aimed at improving normative standards (Braithwaite 2002; Chappell and Polk 2011: 107-111).

Moving even further down the pyramid, from punishment through persuasion, an emerging idea is that the market might act to regulate itself through the aggregate expression of collector preferences. In a climate disapproving of the sale of poorly provenanced or unprovenanced antiquities, collectors might start to discriminate against them by paying higher prices for well-provenanced pieces. Higher prices would in turn encourage the release into the public domain of more provenance-related information, and the market would gradually become more transparent, allowing the collector to be more selective about acquisitions. This suggested process can be termed autoregulation, to emphasize that the mechanism envisaged is something different and apart from self-regulation, which is conventionally understood to comprise cautious restraint on the part of merchants guided by voluntary codes of practice and ethics. Autoregulation denotes action of the neoliberal hidden hand, though with price forcing a legal rather than a quality market.

The idea of antiquities market autoregulation was first mooted by Peter Cannon-Brookes in 1994, when he argued for a 'mechanism of the marketplace itself to create a trading environment which finds illegally excavated, stolen and unlawfully exported cultural property less profitable and thus less attractive' (CannonBrookes 1994: 350). A year later, in 1995, Lisa Borodkin made a similar suggestion, arguing that there were so many fakes on the antiquities market that customers would pay a premium for provenance as the absolute guarantee against forgery. (Although neither Cannon-Brookes nor Borodkin seemed aware of the fact, the economic rationale of autoregulation had already been established by Akerlof (1970) in relation to markets in goods of uncertain quality). Autoregulation does not imply moral agency on the part of collectors. They do not have to be actively selecting well-provenanced objects with a view to minimising the harm caused by the 
antiquities trade. The selection could equally well be prompted by a self-interested belief that a good provenance ensures a high resale price.

Within a few years of Cannon-Brookes and Borodkin suggesting that the market might be placing a premium on artifacts with good provenance, the idea was being floated in the trade literature. A report in the Antiques Trade Gazette, for example, in 1999 suggested that the 'secret of success for the auction houses is to find goods from old private collections which are both desirably fresh and free from possible taint of recent, illegal excavation' (ATG 1999). A New York dealer was quoted as saying in 2004 that 'Within the complex world of the ancient art market it is becoming more apparent that a good provenance has a very positive effect on the value of a work of ancient art' (Russell 2004). The idea of autoregulation also began to spill over into the academic literature (Gerstenblith 2013: 70-72; Mackenzie 2005: 37-38; Adler and Urice 2011: 122 note 27; Norskov 2002: 320; Prott 2000: 348) and to take on the guise of an established reality.

In 2008, a further twist was introduced when the Association of Art Museum Directors (AAMD) adopted a new policy on acquisitions, which stated that a museum

Normally should not acquire a work unless solid proof exists that the object was outside its country of probable modern discovery before 1970, or was legally exported from its probably country of modern discovery after 1970.

The significance of the year 1970 in this context is that it was on 14 November 1970 that UNESCO adopted the Convention on the Illicit Import, Export and Transfer of Ownership of Cultural Property. Other museum organisations such as the International Council of Museums and in the United Kingdom the Museums Association had already adopted 1970 as a threshold or 'bright line' distinguishing between what would be regarded in the museums' world as artifacts with 'bad' (Post-UNESCO) provenance and 'good' (Pre-UNESCO) provenance. Some individual museums, including the British Museum and the J.Paul Getty museum had also by then incorporated the 1970 threshold into their institutional acquisition guidelines. The reasoning behind the adoption of the 1970 date by the AAMD and other museum organisations is that it marks a watershed in museum attitudes and practice, separating off the years before 1970, when the problems caused by illicit trade were either not widely known or thought to be unimportant, from the time afterwards, when the problems became better known and of mounting concern in the museums world. Thus for museums, the 1970 date has come to constitute a strong normative threshold (O'Keefe 2007: 156-158).

Commentator and critic Souren Melikian was quick to explore the implications for market autoregulation of the new AAMD guideline. He surmised that as museums were often the final repository of privately collected antiquities, then private buyers and dealers would be reluctant to purchase antiquities that could not ultimately be donated to museums (Melikian 2008). He also highlighted the unexpectedly high prices achieved by some well-provenanced pieces at the June 2008 antiquities sales of the New York auction houses Sotheby's and Christie's. He concluded that 
These are early signs of a trend bound to gather momentum over the next three to five years.

Antiquities deemed acceptable on the basis of documented early provenance will be avidly fought over. The larger number of those that cannot be conclusively shown to have arrived in the west before 1970 will be increasingly looked at in trepidation by buyers (Melikian 2008).

The welcome result would be that 'At that point, the havoc that illicit digging wreaks on the buried artistic heritage of mankind will be dramatically reduced' (Melikian 2008).

In three later articles, Melikian $(2010 ; 2012 ; 2013)$ went on to argue for the realisation of his own prophecy, again observing high prices being paid for well-provenanced pieces, concluding that 'With the slow but unstoppable force of a juggernaut, the UNESCO Convention for the protection of cultural property ... is reconfiguring the market' (Melikian 2012), and that

Growing numbers of buyers feel that at some point in the not-too-distant future, the Convention will be widely adhered to. Then, costly antiquities bought after 1970 will become hard if not impossible to sell, and their commercial value will nosedive (Melikian 2012),

before finally adding that '... important works of art that can be proved to have reached the market before 1970 shoot to vertiginous levels, while those that cannot fail to sell with increasing frequency' (Melikian 2013). Melikian was not alone in expressing a positive appraisal of the action and effect of autoregulation. It was being more widely reported that the major New York auction houses were turning away artifacts without a secure Pre-UNESCO provenance (Page 2009; Blumenthal and Mashberg 2012), and Christie's head of antiquities was quoted as saying that 'Provenance used to play second fiddle to quality and beauty, but now it is king and reigns supreme' (Page 2009).

Mention of quality and beauty, however, brings forward a set of potentially confounding considerations. While he was headlining the positive market effect of a Pre-UNESCO provenance, Melikian was more quietly suggesting that the art historical importance of a piece (its importance in terms of what is known about its original manufacture and function, or its place in scholarship) was also positively influencing price (Melikian 2010). Dealer Rupert Wace offered another perspective when he was quoted in 2009 as saying that artistic quality was the most sought after object attribute (Page 2009). The curator of Greek and Roman art at the Michael C. Carlos Museum echoed that 'provenance is a crucial aspect that must be considered, but it is not the overriding factor. Beauty and importance are also significant: by far the most important aspect to consider when acquiring an object is the object itself' (Russell 2004). The distinction between the aesthetic or artistic significance of a piece (judged by formal properties of appearance, or 'beauty') and its art historical importance will not be explored here. Instead, in what follows, both will be considered together as components of object quality and therefore as a determinant of price. 
The prices adduced to support of the idea of market autoregulation have been limited to those achieved in a handful of exceptional performances at auction by objects with long provenances. Borodkin, for example, refered to record-breaking prices achieved by a ninth-century BC Assyrian relief sold for $£ 7.7$ million in 1994 (Borodkin 1995: 412 note 223) and a third-millennium BC Greek Cycladic figurine sold for \$2.09 million in 1988 (Borodkin 1995: 383-4 note 43). But these types of object are of high quality too, and it is not immediately clear how the determining influences of quality and provenance on price can be disentangled. An extreme example of this phenomenon was seen at Sotheby's New York on 5 December 2007 when a small, limestone figure of a lioness (the Guennol Lioness), dating to between 3000-2800 BC and only $8.26 \mathrm{~cm}$ high, exceeded the pre-sale estimate of between \$14-18 million to achieve a hammer price of just over \$57 million. At the time, this was a record price for an antiquity ${ }^{1}$. Indeed, it was a record price for any piece of sculpture sold at auction ${ }^{2}$. The lioness was found in Iraq before 1931 and had been extensively published since then , and is widely regarded to be an object of exquisite beauty. Whether the $\$ 57$ million price tag should be attributed to its artistic significance, art historical importance, long provenance, or a combination of all three, is not possible to say from the evidence of that single sale alone.

Table 1. The earliest verifiable provenances of the five highest-priced objects sold at Sotheby's New York on 17 December 2010, together with Melikian's (2010) comments.

\begin{tabular}{|c|c|c|c|c|}
\hline Lot no. & $\begin{array}{l}\text { Median } \\
\text { estimate }\end{array}$ & $\begin{array}{l}\text { Realized } \\
\text { price }\end{array}$ & Provenance & Melikian comment \\
\hline 3 & 200,000 & 842,500 & $\begin{array}{l}\text { Mathias Komor, } \\
1976\end{array}$ & $\begin{array}{l}\text { 'The bronze is a supreme example of an } \\
\text { object that is likely to be unobtainable in } \\
\text { the future, both because collections such } \\
\text { as Mr. Day's are increasingly rare - the } \\
\text { knowledge, the patience, the dedication } \\
\text { are gone - and because when pieces of } \\
\text { this caliber, previously unrecorded, turn up, } \\
\text { questions are asked about the legitimacy of } \\
\text { their acquisition' }\end{array}$ \\
\hline 4 & 350,000 & 662,500 & $\begin{array}{l}\text { Koutoulakis; } \\
\text { published } 1987\end{array}$ & 'Similar thoughts ...' \\
\hline 9 & $2,500,000$ & $23,826,500$ & Published 1879 & $\begin{array}{l}\text { 'It is only in such a context that the price } \\
\text { paid ... can be understood' }\end{array}$ \\
\hline 25 & $1,000,000$ & $5,234,500$ & Published 1972 & $\begin{array}{l}\text { 'However, it is in the sphinxes' nature to be } \\
\text { enigmatic, and } 1972 \text { is close enough to } \\
\text { 1970' }\end{array}$ \\
\hline 27 & 250,000 & $1,314,500$ & Published 1929 & $\begin{array}{l}\text { 'new luster acquired by Egyptian historic } \\
\text { sculpture with a documented record } \\
\text { meeting the Unesco criteria' }\end{array}$ \\
\hline
\end{tabular}

\footnotetext{
${ }^{1}$ The previous record had been set in June 2007 when a Roman bronze figure of Artemis and the Stag, known since 1953 when it was acquired by the Albright-Knox Art Gallery in Buffalo New York, exceeded its pre-sale estimate of \$5-7 million when it sold for $\$ 28.6$ million (Baugh 2007).

2 The previous record had been $\$ 29$ million for a piece by Pablo Picasso (Baugh 2007).
} 
Sometimes, however, exceptionally-priced objects are sold with short (Post-UNESCO) provenances. Table 1, for example shows the five highest price objects sold at Sotheby's New York, 17 December 2010 as reported by Melikian (2010), together with their earliest date of provenance and Melikian's comments. These were the sold lots used by Melikian to support his contention of market autoregulation. In fact, and undermining Melikian's argument, only two out of the five pieces had a provenance extending back to before 1970; the provenances of the remaining three pieces were all Post-UNESCO. In those instances, the high prices must be credited to the quality of the object in question, not to the length of its provenance. Thus while eyecatching combinations of provenance and price might suggest a strong causal relation and be interpreted as evidence of autoregulation, a stronger underlying relationship might be the one between object quality and price - the normal market relationship in fact.

To date, there has been no systematic examination of auction price data to test the strength or causality of the association between provenance and price, and thus the reality of market autoregulation. This paper makes good this deficiency by presenting the results of four analyses. The first analysis looks for evidence of any effect of provenance on the saleability or price of objects offered and sold at four auctions. After a short excursus that considers the effect of collectors' choice on the market, in the second analysis the question of autoregulation is turned on its head as the price and saleability of objects with an overtly suspicious provenance are examined for evidence of negative market performance. The third analysis builds on the first two by considering how object provenance might be associated with object quality, and how this association might impact on saleability and price. The final analysis controls for the confounding effect of object quality by examining repeat sales data for evidence of any changing effect of provenance on price through time.

\section{Analysis 1: The effect of provenance on saleability and price}

This first analysis examines the strength of association at auction between the provenances of lots and their saleability and mean prices. The test data were taken from four separate auction sales: Sotheby's New York 7 December 2010 (Antiquities from the Collection of the Late Clarence Day) and 7 June 2012 (Antiquities); and Christie's London 14 April 2011 (Antiquities) and 6 October 2011 (Antiquities). The Sotheby's sales are among those discussed by Melikian (2010; 2012). A total of 742 lots were offered at these sales, and 602 lots sold.

Often, some information about provenance is included in catalogue entries for individual lots, although it is not usually detailed or comprehensive, and hardly ever complete. For this analysis, provenance was assessed as verifiable provenance, not published provenance. This means that the earliest date of provenance of a lot is determined either from the conjunction of a previous owner's name and date of ownership, or from a publication date. In theory, this information would provide a potential customer with the wherewithal to verify independently the facts being offered about provenance, something that would not be possible with some of the more common 'provenance' descriptions to be found in auction catalogues, such as 'Property of a gentleman'. Verifiable provenance is a weaker measure of provenance than published 
provenance as it is harder to verify and thus easier to falsify. It was chosen for statistical reasons to produce comparably-sized groups as only a small proportion of lots are accompanied by a published provenance. On the basis of verifiable provenance, each lot was allocated to one of three provenance groups, defined as follows: (1) Pre-UNESCO, with an earliest verifiable provenance dating to before 14 November 1970 (the date of adoption of the 1970 UNESCO Convention); (2) Post-UNESCO, with an earliest verifiable provenance dating to on or after 14 November 1970; and (3) Uncertain, lots with no provenance or with an undated provenance.

Saleability is expressed by the percentage lots sold at each sale in each provenance class. If the antiquities market is subject to autoregulation, the expectation would be that the percentage of lots selling with a Pre-UNESCO provenance should be higher than the percentages selling with either a Post-UNESCO or an uncertain provenance. Mean price is the mean price of all lots sold in each provenance class at each sale. Again, if autoregulation is operational, the expectation would be that in any one sale the mean price of lots sold in the Pre-UNESCO provenance class should be higher than that achieved for the other provenance classes.

Table 2. The saleability of lots classified according to provenance and sold at auction Sotheby's New York, 7 December 2010

\begin{tabular}{|l|l|l|l|}
\hline & Lots offered & Lots sold & Percent \\
\hline Pre-UNESCO & 12 & 12 & 100 \\
\hline Post-UNESCO & 25 & 25 & 1 \\
\hline Uncertain & 1 & 47 & 100 \\
\hline Total & 47 & 47 & 100 \\
\hline
\end{tabular}

No significant difference

Sotheby's New York, 7 June 2012

\begin{tabular}{|l|l|l|l|}
\hline & Lots offered & Lots sold & Percent \\
\hline Pre-UNESCO & 40 & 34 & 85 \\
\hline Post-UNESCO & 20 & 14 & 70 \\
\hline Uncertain & 19 & 14 & 74 \\
\hline Total & 79 & 62 & \\
\hline
\end{tabular}

No significant difference $\left(X^{2}=2.11\right.$, df $\left.2, p=>0.05\right)$

Christie's London, 14 April 2011

\begin{tabular}{|l|l|l|l|}
\hline & Lots offered & Lots sold & Percent \\
\hline Pre-UNESCO & 149 & 133 & 89 \\
\hline Post-UNESCO & 92 & 68 & \\
\hline Uncertain & 124 & 95 & 74 \\
\hline Total & 365 & 296 & 77 \\
\hline
\end{tabular}

Significant difference $\left(X^{2}=11.2\right.$, df $\left.2, p=<0.01\right)$

Christie's London, 6 October 2011

\begin{tabular}{|l|l|l|l|}
\hline & Lots offered & Lots sold & Percent \\
\hline Pre-UNESCO & 34 & 26 & 76 \\
\hline
\end{tabular}




\begin{tabular}{|l|l|l|l|}
\hline Post-UNESCO & 144 & 121 & 84 \\
\hline Uncertain & 73 & 50 & 68 \\
\hline Total & 251 & 197 & \\
\hline
\end{tabular}

No significant difference $\left(X^{2}=7.04\right.$, df $\left.2, p=>0.05\right)$

Table 3. The mean price of lots classified according to provenance and sold at auction

Sotheby's New York, 7 December 2010

\begin{tabular}{|l|l|l|l|}
\hline & Pre-UNESCO & Post-UNESCO & Uncertain \\
\hline Mean price $(\$)$ per lot & $2,287,365$ (no. = 12) & 370,360 (no. = 25) & -- \\
\hline
\end{tabular}

(But, lot 9, prov 1870s, $\$ 23,826,500$ )

\begin{tabular}{|l|l|l|l|}
\hline & Pre-UNESCO & Post-UNESCO & Uncertain \\
\hline Mean price (\$) per lot & $329,261($ no. $=11)$ & $370,360($ no. $=25)$ & -- \\
\hline
\end{tabular}

(Excluding lot 9)

Sotheby's New York, 7 June 2012

\begin{tabular}{|l|l|l|l|}
\hline & Pre-UNESCO & Post-UNESCO & Uncertain \\
\hline Mean price (\$) per lot & $125,533($ no. $=34)$ & $20,491($ no. $=14)$ & $36,339($ no. $=14)$ \\
\hline
\end{tabular}

Significant difference (One-way ANOVA, df 2, $F=4.406, p=0.05>0.01$ )

Christie's London, 14 April 2011

\begin{tabular}{|l|l|l|l|}
\hline & Pre-UNESCO & Post-UNESCO & Uncertain \\
\hline Mean price $(\mathrm{f})$ per lot & $20,099$ (no. $=133)$ & $18,088$ (no. $=68)$ & $9,948$ (no. $=95)$ \\
\hline
\end{tabular}

No significant difference (One-way ANOVA, df 2, $F=1.703, p=>0.05$ )

Christie's London, 6 October 2011

\begin{tabular}{|l|l|l|l|}
\hline & Pre-UNESCO & Post-UNESCO & Uncertain \\
\hline Mean price (f) per lot & $35,905$ (no. $=26)$ & $12,560($ no. $=121)$ & $20,772(50)$ \\
\hline
\end{tabular}

No significant difference (One-way ANOVA, df 2, F = 2.860, $p=>0.05$ )

The results are shown in Tables 2 and 3. There are no consistent significant differences between provenance classes when compared for either saleability or mean price. Two exceptions are Christie's London, 14 April 2011, when in terms of saleability lots in the Pre-UNESCO class outperformed those in other provenance classes, and Sotheby's New York, 7 June 2012, when the Pre-UNESCO lots achieved a higher mean price than those lots in other provenance classes. These results suggest at best a mild positive effect of PreUNESCO provenance on saleability and price. But while a Pre-UNESCO provenance might be influencing the purchasing preferences of some collectors, it can hardly be said to be 'reconfiguring the market' in the way claimed by Melikian, and it falls far short of any materially effective expression of market autoregulation. It must be remembered too, in anticipation of what follows next, that this first set of comparisons takes no account of the potentially confounding effect of object quality on saleability and price. 


\section{Excursus: On the wealth and taste of collectors}

A point of interest in the first analysis is the mean price data of the Sotheby's New York, 7 December 2010 sale, which show a significantly higher mean price for the Pre-UNESCO provenance group, although a difference that is due entirely to the distorting effect of the abnormally-high price paid $(\$ 23,826,500)$ for lot 9 , a Roman marble bust with a provenance stretching back to 1879. When lot 9 is excluded from consideration, the price differential across provenance classes disappears along with it. The unexpected and exceptional performance of lot 9, which sold for more than nine times its median estimated price of \$2.5 million, illuminates the importance of object quality on price determination. The piece in question is a Roman marble portrait bust of the youth Antinous, a known historical figure who was a favourite of the Emperor Hadrian, and it carries an inscription recording its dedication by Marcius Lucius Flaccus, another historically-identifiable person. Since the bust's discovery in 1879, it has featured in several scholarly monographs, articles and catalogues, thus ensuring its status as a work of known art historical importance, and perhaps too its unexpectedly high hammer price. To place the Antinous in some sort of comparative art historical perspective, it is worth considering lot 25 in the same Sotheby's New York 7 December 2010 sale, which at \$5,234,500 was second in price only to the Antinous bust, selling for more than five times its median estimate. Lot 25 was a Roman porphyry sphinx dating to AD 81-96 and thought to have been made in imitation of an Ancient Egyptian original. The Egyptian original, which is presently in an Italian museum, had been moved to Rome in antiquity, where it was discovered in the 1850s on the site of a temple restored by the Roman Emperor Domitian towards the end of the first century AD (Sotheby's 2010: 59). It is thought that the Roman copy sold at Sotheby's might have been manufactured at the same time for installation in the same temple. In consequence, like the marble Antinous, the sphinx has featured in several scholarly publications ${ }^{3}$. Unlike the Antinous, however, the sphinx has only a limited provenance. The associated catalogue entry suggests that it might have been found before the Second World War, but the earliest verifiable provenance is 1972, when it was first published. Thus the high price awarded to the sphinx cannot be because of its provenance, it is more likely to be because of its perceived art historical importance. For both the Antinous and the sphinx, then, it can be argued that it was object quality driving up price, as, in the case of the sphinx at least, it was not a PreUNESCO provenance. (Unless the 1970 'bright-line' is viewed less rigorously as only an approximate guide, which is a problem of ethical semantics that cannot be addressed here).

The art historical importance of the Antinous and the sphinx draws attention to another important feature of the Sotheby's New York, 7 December 2010 sale, which is that the objects sold had all been the property of the recently-deceased private collector Clarence Day. The auction catalogue described Day's collection as exhibiting a 'high level of quality and connoisseurship' (Sotheby's 2010: 9), and the high prices fetched at auction for the ex-Day material when contrasted to the prices achieved at other sales under consideration here (Table 3) bear that statement out. Thus the high prices were due to choices made by Day

\footnotetext{
3 Though as the context and circumstances of its discovery remain unknown, its historical significance is really only a matter for conjecture.
} 
when selecting objects according to certain criteria of artistic or art historical worth and within the financial means available to him. In other words, the objects offered for sale at Sotheby's on 7 December 2010 did not comprise a representative sample of those available on the antiquities auction market more generally - thanks to Day's taste and available budget they were of above average quality.

Almost by definition, any object appearing on the market in the 2000s with a Pre-UNESCO provenance will have passed through the hands of one or more collectors, and will therefore have been subject to the filtering effects of their tastes and budgets (Norskov 2002: 301-311). Successive collectors would have chosen 'good' objects and rejected 'poor' objects. The longer an object has been in circulation, the more prolonged and cumulative the filtering effect will have been. Thus it should be expected a priori that on average objects coming to market with a long provenance will be of higher artistic or art historical quality than objects with only a short provenance, and it should in consequence be no surprise when higher-priced objects have a long provenance, or when collections of objects with long provenances such as that of Day attract high prices. It is not the length of provenance in itself that is setting price, but the perceived quality of the objects, as endorsed by their collecting histories and associated scholarship.

Although the data in Table 1 offer only slight evidence of a difference in price between long and short provenance objects, the implication of the preceding argument is that recently-looted objects reaching the market with a short or no provenance are on average of poorer quality than objects that have long been in circulation. But it is well-known that some high-profile, illicitly-traded pieces have broken price records when they were first sold (Nørskov 2002: 291-2). Thus it must be remembered that public auctions do not constitute the entirety of the antiquities market, and that recently illicitly-traded, high-quality objects might not be sold at auction. There is a thriving trade to be seen on the Internet, there are physical sales galleries that may be visited by collectors, and there are private treaty sales. Nørskov (2002: 291-2) characterised these private sales as comprising an 'invisible market', pointing out that the invisible market was in the past the source of many important museum acquisitions, and that the prices agreed in many of these invisible transactions were higher than anything achieved at auction ${ }^{4}$. A recent example would be the purchase in 1998 by the St Louis Art Museum of the eleventh-century BC funerary mask of Egyptian noblewoman Ka-Nefer-Nefer from a New York dealership for $\$ 499,000$. The mask is alleged to have been stolen from a storeroom in Egypt and is the subject of a recovery claim (Gay 2012). Thus high-quality poorly provenanced objects might simply be by-passing the public auction market because of doubts about their origins. There are certainly some well-known private collections of largely unprovenanced high-quality objects that have been assembled over the past twenty or thirty years (Chippindale and Gill 2001), some by auction and some not, including objects that are openly suspected of having been recently looted - the 'toxic' antiquities of David Gill'. Such collections are the ones

\footnotetext{
${ }^{4}$ The first million dollar museum acquisition was in 1972 when the Metropolitan Museum of Art paid \$1 million to dealer Robert Hecht for the Attic 'Euphronios' krater. Several more multi-million dollar museum acquisitions followed before the first object to break the million dollar barrier at auction in 1988, in the sale noted by Borodkin when a Cycladic figurine fetched \$2.09 million in New York (Nørskov 2002 : 291-2). ${ }^{5}$ http://lootingmatters.blogspot.co.uk/2013/01/toxic-antiquities-sothebys-and-1985.html
} 
containing antiquities with short or no provenance that in quality can stand comparison with the antiquities in the Day collection. If such collections are being deliberately withheld from the public gaze of the auction market, however, it might suggest that their owners or the auction houses themselves are wary of the obloquy and police attention that a sale might attract, and that autoregulation is, after all, in effect. Such collections will have become unsaleable to such a pitch that sale by auction is not even attempted. The possibility that a suspect or 'toxic' provenance might deter sale at auction is addressed in analysis two, which examines the sale in October 2008 at the London auction house Bonhams of material from the collection of Graham Geddes. Geddes, described by Bonhams as 'Australia's foremost dealer and collector' (Rountree 2008, 43), had built up his collection from the 1970 s onwards.

There is one further point to bear in mind. To the extent that quality assessment is inter-subjective, it is possible that attributions of artistic or art historical importance might accrete, so that in effect the quality of an object is something that can be created, agreed, recognized or discovered and thus improve over time. It is also the case that the reputation of a collector might in itself add to the market value of a piece, either because of a collector's celebrity, which might add associative lustre, or because of high regard for a collector's taste, which would then act as a proxy judgement or imprimatur of quality. If this view of quality as a consensual product is correct, then the quality of objects only recently arrived on the market might be better considered as uncertain than as poor, and that it is customer uncertainty over quality that is depressing prices (Akerlof 1970) rather than autoregulation.

The probability that the wealth and taste of collectors might over the long-term act to filter out objects of poorer quality is tested in analysis three with reference to seven lots from the estate of Jan Mitchell sold at Sotheby's in 2012. Mitchell, who died in 2009, was a wealthy collector specialising in Precolumbian gold artifacts. While he was trustee in 1993 he donated his collection to the Metropolitan Museum of Art and paid for the renovation of a gallery there which was subsequently named the Jan Mitchell Treasury in his honour (Grimes 2009; Jones 1985). Mitchell is exactly the type of discriminating and wealthy collector who would be expected to acquire only antiquities of exceptional quality.

\section{Analysis 2: The effect of suspect provenance on saleability and price}

On 15 October 2008, the London auction house Bonhams sold 120 of 180 offered lots from the collection of Graham Geddes. The sale had originally comprised 193 lots, but the day before auction the Italian authorities informed Bonhams that 10 pieces probably derived from illegal digs conducted during the 1970s, and Bonhams subsequently withdrew 13 pieces from auction (Squires 2008). Four of the withdrawn pieces were South Italian pottery vessels that had been acquired at Sotheby's London in the 1980s. Large numbers of unprovenanced South Italian vessels and other types of painted Greek pottery being sold at Sotheby's London in the 1980s and early 1990s had been consigned by the dealer Giacomo Medici who was convicted in 2004 of receiving and illegally exporting stolen antiquities (Watson and Todeschini 2007). It is known that Geddes bought at least one of the Medici pieces, because it is illustrated in a book reporting the investigation (Watson 
1997: pl. opp. 186), though it was not offered in the Bonhams sale. It should now be common knowledge in the collecting and sales communities that any South Italian or Classical Greek pottery with a provenance dating back only to the 1980s or 1990s was quite possibly excavated and traded illegally, particularly if it was sold through Sotheby's, and that its acquisition or sale should be avoided unless there is evidence at hand to prove otherwise. Nevertheless, undeterred, Bonhams went ahead with the Geddes sale. (This decision by itself is proof that some auction houses at least are not deterred by the taint of a suspect provenance, and that again autoregulation is not obviously in evidence).

Table 4. The saleability of Greek and South Italian painted pottery from the Graham Geddes collection offered for sale at Bonhams London on 15 October 2008.

\begin{tabular}{|l|l|l|l|}
\hline & Lots offered & Lots sold & \% sold \\
\hline Non-Sotheby's & 25 & 23 & 92 \\
\hline Sotheby's & 20 & 17 & 85 \\
\hline
\end{tabular}

No significant difference $\left(X^{2}=0.58\right.$, df $\left.1, p=>0.05\right)$

Table 5. The mean price of Greek and South Italian painted pottery from the Graham Geddes collection offered for sale at Bonhams London on 15 October 2008.

\begin{tabular}{|l|l|}
\hline & Mean price $(\mathrm{f})$ \\
\hline Non-Sotheby's & $7,341(\mathrm{n}=23, \mathrm{sd}=10,461)$ \\
\hline Sotheby's & $11,343(\mathrm{n}=17, \mathrm{sd}=9,622)$ \\
\hline
\end{tabular}

No significant difference (two-tailed t test, $p=<0.05$ )

The auction included 52 lots of Classical Greek or South Italian pottery. Seven of the lots were among those withdrawn at the request of the Italians, and five failed to sell. None of the 40 lots that actually sold had a long provenance, they were all Post-UNESCO, but they could be divided into two provenance groups. The first group, 17 lots in total, had been acquired at Sotheby's London in the 1980s. The remaining 23 lots had been acquired from other sources. If the market is subject to autoregulation, it might be expected that objects with an obviously suspect provenance (those bought at Sotheby's), would perform less well than those with a seemingly better provenance (those not bought at Sotheby's). Tables 4 and 5 show that in terms of saleability and mean price there are no significant differences between the Sotheby's and Not-Sotheby's groups, and thus there is no evidence of market autoregulation.

The sale of the Geddes collection also suggests that the large privately-assembled collections of unprovenanced and suspect antiquities discussed in the preceding excursus are not being held back from the auction market for reasons of poor provenance. It is instead possible that some at least are being withheld because they are destined to become museum donations, and it is notable in this regard that the AAMD in January 2013 altered its 2008 guidelines to allow the acquisition by gift or bequest of collections containing 
material of Post-UNESCO provenance provided the donation had been agreed before the adoption of the 2008 policy and that there is evidence of that fact ${ }^{6}$.

Since the Geddes sale, it has been alleged on the basis of photographic evidence obtained during the Italian investigation of Medici that five of the lots offered for sale at Christie's New York 6 June 2013 Antiquities auction must have been illegally traded (Gill 2013). Nevertheless, even these allegations of downright illicit provenance did not unduly dampen customer interest, with three of the five pieces selling, a saleability comparing well with the overall rate of $70 \%$ for the auction as a whole. Another study of Christie's auction sales has similarly concluded that the 1970 threshold is having no discernible effect on the market (Tsirrogiannis 2013: 16).

\section{Analysis 3: The effect of collectors' choice on the antiquities market}

The material from the collection of Jan Mitchell was sold in the Sotheby's New York 7 June 2012 sale. Sotheby's sold 34 Pre-UNESCO lots that day, the seven already noted from the Mitchell collection, and 27 other lots, that must also have passed through the hands of one or more collectors before the June 2012 sale, though from the information provided in catalogue entries none as prominent as Mitchell. With a Pre-UNESCO provenance, the performance at auction in 2012 of all this material should not have been adversely affected by any concerns about recent illicit trade, it should have been determined solely by quality. Following the argument developed in the excursus about the choice of wealthy collectors, it would be expected that the exMitchell Pre-UNESCO lots would be of better quality than the other lots, and would therefore command higher prices, which is in fact the case (Table 6). Like Day, the wealth and taste of the collector (Mitchell) is clearly reflected in the high quality and thus price of the objects he collected.

Table 6. The mean prices of lots sold at Sotheby's New York from the Mitchell collection and of all remaining lots with a Pre-UNESCO provenance

\begin{tabular}{|l|l|}
\hline Mitchell & All other lots \\
\hline$\$ 313,643($ no. $=7)$ & $\$ 77,875($ no. $=27)$ \\
\hline
\end{tabular}

If the broader argument being proposed here is correct, that on average the quality of an object is positively correlated with its length of provenance, then it would be expected that price should also be correlated with length of provenance. This proposition was tested by dividing the Sotheby's New York 7 June 2012 sale data into two groups, again using only the 34 Pre-UNESCO lots so as to exclude any possible interfering effects on price of autoregulation. The date of 1930 was chosen as a chronological separator to divide the material into two nearly equally-sized groups, of 16 (Pre-1930) and 18 (1930-1970) lots respectively. Four of the Mitchell lots were allocated to the Pre-1930 group (with provenances in three cases dating back to before 1900), with the remaining three lots falling into the 1930-1970 group (all with provenances dating back

${ }^{6}$ https://aamd.org/sites/default/files/document/Guidelines\%20on\%20the\%20Acquisition\%20of\%20Archaeolo gical\%20Material\%20and\%20Ancient\%20Art\%20revised\%202013 0.pdf 
to the 1960s). Comparison of the mean prices of the groups allows two things to be measured: (1) the association between provenance and price on a data set that is unaffected by any potential ethical or financial concerns in 2012 relating to the 1970 date of the UNESCO Convention; and (2) the outcome in terms of object quality and thus price of Mitchell's actions as a collector. Table 7 shows the mean prices achieved by lots in these groups. Two things are apparent: (1) the mean prices of lots with a pre-1930 provenance are higher than that those with a 1930-1970 provenance. (The difference would probably be more pronounced if the Mitchell Pre-1930 lot 15 had not been fragmentary, selling for only \$74,500); (2) in each provenance group, the mean price of the Mitchell lots is higher than the mean price of the remaining (non-Mitchell) lots. This difference was expected given the observation made earlier that Mitchell was a discriminating and wealthy collector. The figures presented in Table 7 suggest that in the Mitchell collection and overall the better quality and thus higher priced pieces were those that had been in circulation for a longer time, surviving in some cases several hundred years' collecting and with the associated long documented ownership histories and scholarly references to match. Thus although there is a correlation between provenance and price, as all provenances were Pre-UNESCO, and therefore good, the price difference cannot be attributed to concerns about recent illicit trade. The causal variable must be object quality, selected and constructed through time by the action of collectors' choice. Table 8 shows similar price differentials for the other auctions considered in this paper ${ }^{7}$, with the higher prices paid for the Clarence Day groups confirming the point already made for Mitchell. Viewing the results of Tables 7 and 8 in the context of Table 3 further confirms the positive effect of object quality as mediated through long provenance.

Table 7. The mean prices of four groups of lots sold at Sotheby's New York, 7 June 2012 with Pre-UNESCO provenance

\begin{tabular}{|l|l|l|}
\hline & Mitchell & All other lots \\
\hline Pre 1930 & $\$ 362,500($ no. $=4)$ & $\$ 107,042($ no. $=12)$ \\
\hline $1930-1970($ UNESCO) & $\$ 248,500($ no. $=3)$ & $\$ 54,542($ no. $=15)$ \\
\hline
\end{tabular}

Table 8. The mean prices of lots with a Pre-UNESCO provenance further subdivided into groups comprising lots with a Pre-1930 or a 1930-1970 provenance.

Sotheby's New York 7 December 2010 (Clarence Day)

\begin{tabular}{|l|l|}
\hline Pre 1930 & $\$ 6,448,500($ no. $=4)$ \\
\hline $1930-1970$ & $\$ 206,797$ (no. $=8)$ \\
\hline
\end{tabular}

Christie's London 6 October 2011

\footnotetext{
7 Data from Christie's London 14 April 2011 were not included because of the quantity of material from the Empain Collection, which had all been acquired sometime between 1905 and 1929, thus preventing a good division of material based on a 1930 date.
} 


\begin{tabular}{|l|l|}
\hline Pre 1930 & $£ 96,754$ (sd 131,075, no. $=6)$ \\
\hline $1930-1970$ & $£ 17,650$ (sd 42,223 no. $=20)$ \\
\hline
\end{tabular}

Significant difference (Two-tailed t test, $p=0.05>0.01$ )

It is clear from this analysis that in aggregate and over the long term, the action of collectors' choice exerts a filtering effect on the market, preferentially selecting antiquities of good quality. Thus although the provenance and price of pieces appear to be correlated, the association is due in large part to the better quality of objects with long provenance, which in turn reflects the discriminating agency of successive collectors and their quest for quality, not the ethical or financial qualms of present-day purchasers. This is not the autoregulation envisaged by Cannon-Brookes and Melikian. And it should be emphasized here that the dividing date of 1930 used in this set of comparisons was chosen simply because it divided the available data into two approximately equal sized groups. On another day, with another data set, a different date might have been chosen. Thus the 1930 date does not exert any 'thresholding' effect as regards price performance. While remembering and accepting the likely presence on the invisible market of high-value illicitly-traded antiquities, the results of this analysis should be taken in a preliminary way as hypothesizing a uniform relation between length of provenance and object quality for objects sold at auction, so that in general the longer an object has been in circulation the better it should perform at auction, thus explaining the significant price differences seen between provenance groups in Table 3.

\section{Analysis 4: The effect of provenance on price appreciation through time}

The fourth analysis excludes the filtering action of collector agency and overcomes the confounding effect of object quality on price by comparing prices from repeat sales of the same object. For the analysis, 163 data pairs were collected for objects sold twice after 1980 - once in 2005 and once in another year. There are 30 data pairs for objects with a Pre-UNESCO provenance, and 132 data pairs for objects with a Post-UNESCO provenance. By using repeat data from single objects, any difference in rates of price increase between provenance groups since 1970 should not be unduly influenced by changing perceptions of quality, and would instead suggest the action of autoregulation. All prices were corrected for inflation and prices in GB pounds were converted to US dollars. Each non-2005 sale price was then standardised as a decimal fraction or multiple of the 2005 sale price for same object, with the 2005 price set at 1 . All non-2005 standardised sale prices were then graphed, and curves fitted to the Pre-UNESCO and Post-UNESCO data plots to show for each group the mean change in price through time.

Figure 1. Plot of 2005-standardised price against time. Pre-UNESCO: dashed curve (exponential, R2 = 0.4863); Post-UNESCO: solid curve (exponential, R2 $=0.4342$ ). 


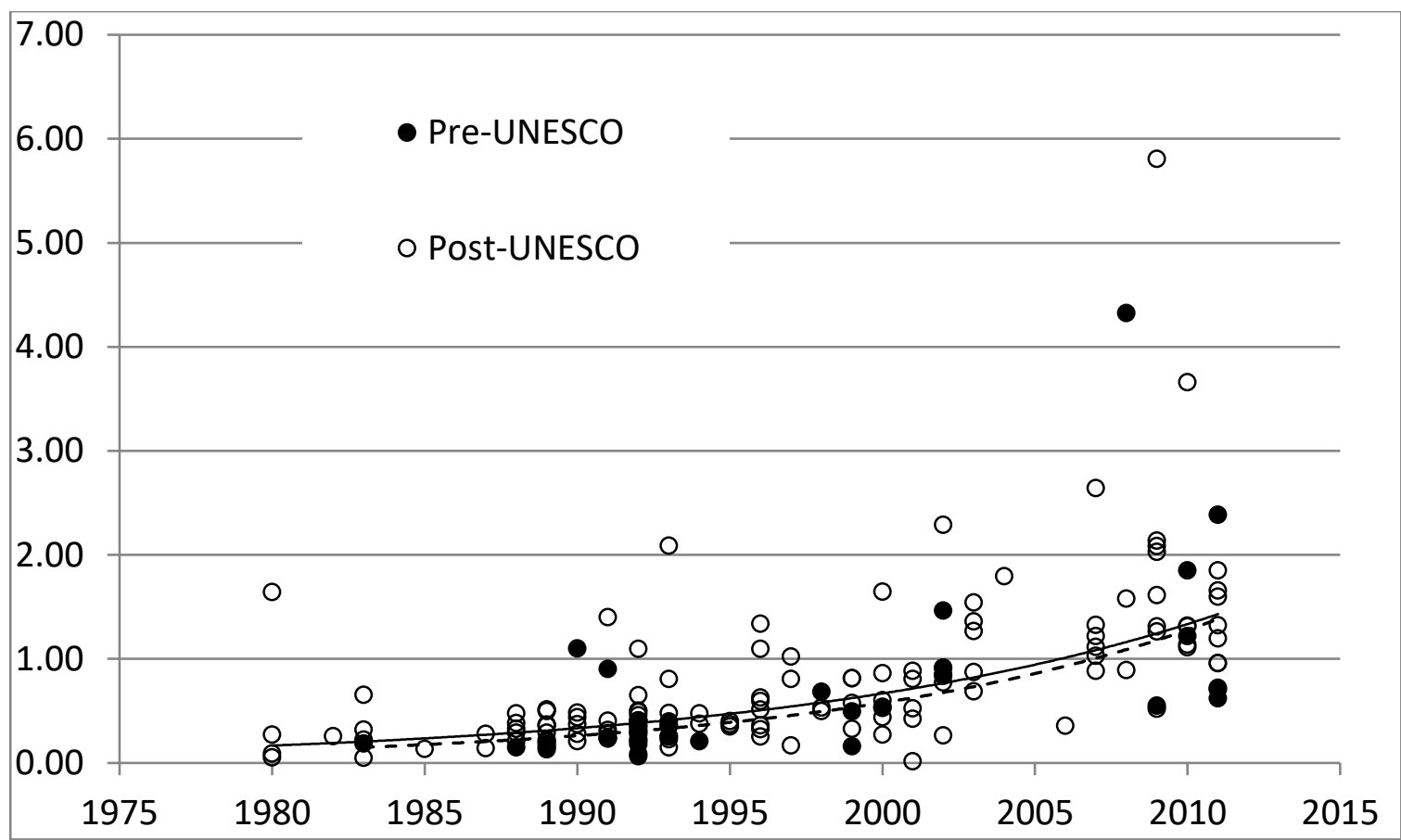

The plot is presented in Figure 1. If Pre-UNESCO provenance was becoming an increasingly important determinant of price through the 2000s, it would be expected that the gradient of the Pre-UNESCO curve would increase more sharply than that of the Post-UNESCO curve. That expectation is not met. Although there is a large degree of individual variation, on average, both groups of object seem to be increasing in price at similar rates. There is no evidence of autoregulation acting to depress Post-UNESCO prices or to elevate PreUNESCO prices.

\section{Discussion}

The analyses presented in this paper found no strong evidence of autoregulation of the antiquities market acting to promote the trade of antiquities with a Pre-UNESCO provenance, while at the same time discouraging the trade in antiquities without such a provenance. What slight evidence there is of an association of between provenance and price seems more likely to be because of the higher quality of objects with long provenance. It remains now to consider why the 1970 date is not exerting the regulatory effect on the market that commentators and scholars believe it should be, and why too these commentators and scholars believe that it is exerting an effect when the evidence to hand suggests otherwise.

Questions can certainly be asked about the legitimacy and perceived legitimacy of the 1970 threshold. The 1970 UNESCO Convention has now been recognised by several courts as comprising international public policy (O'Keefe 2007: 163-165), but nowhere does it establish that the date of 1970 should be a legal watershed for object provenance. Although the Convention was adopted in November 1970, it did not enter force until 24 April $1972^{8}$, and States have been gradually acceding to the Convention ever since,

${ }^{8}$ http://portal.unesco.org/en/ev.php-URL ID=13039\&URL DO=DO TOPIC\&URL SECTION=201.html) 
most recently in $2012^{9}$. The Convention is not retroactive, and thus its obligations only apply to a State Party after accession. Furthermore, in its early years it was weakened by the delayed accession of major market countries such as the United States (1983), France (1997), the United Kingdom (2002) and Switzerland $(2003)^{10}$. Thus the 1970 date of adoption has no meaning in international law, although symbolically it marks an ethical watershed (Brodie, Doole and Watson 2000: 9). For that reason, and for that reason alone, the 1970 date has been adopted as a normative threshold within the museums community.

Professional associations of antiquities dealers have their own codes of ethical practice (O'Keefe 2000; 2007: 159-62), but they are not concerned with the 1970 threshold. Even UNESCO's own recommended International Code of Ethics for Dealers in Cultural Property makes no mention of a 1970 threshold. The reason for this seeming lack of interest in the date is not hard to divine. Many countries have taken cultural and archaeological heritage into State ownership by means of so-called patrimony laws, and are prepared to commence civil or criminal court proceedings for the recovery of illicitly-traded antiquities using appropriate stolen property laws. The date of vesting legislation varies from country to country, but invariably is earlier than 1970, and is regarded by the country concerned as the relevant and legally-enforcible date underpinning property claims. In 1987, for example, Turkey commenced ultimately successful court proceedings against New York's Metropolitan Museum of Art aimed at recovering the so-called Lydian Hoard, an assemblage of more than 360 precious artifacts that had been looted and illegally traded from Turkey sometime during the 1960s, and acquired by the Metropolitan later that same decade (Kaye and Main 1995). Turkey took antiquities into State ownership in 1906 (Blake 1998: 826), and the 1970 date of the UNESCO Convention was immaterial to the case. For dispossessed countries such as Turkey, the adoption of a 1970 threshold discriminating between licitly- and illicitly-traded antiquities would be akin to relinquishing legitimate claims to ownership of property stolen prior to 1970, an action that if taken would be against their own best interests. The existence of these legally-enforcible property claims is the hard legal reality facing antiquities dealers, and it is reflected in the UNESCO code for dealers, for example, where Article 1 states that:

Professional traders in cultural property will not import, export or transfer the ownership of this property when they have reasonable cause to believe it has been stolen, illegally alienated, clandestinely excavated or illegally exported. ${ }^{11}$

Article 2 of the International association of Dealers in Ancient Art (IADAA) similarly states that:

\footnotetext{
${ }^{9}$ http://www.unesco.org/eri/la/convention.asp?KO=13039\&language=E).

${ }^{10}$ http://www.unesco.org/eri/la/convention.asp?KO=13039\&language=E\&order=alpha

${ }^{11} \mathrm{http} / / /$ portal.unesco.org/culture/en/ev.php-URL_ID=13095\&URL_DO=DO_TOPIC\&URL_SECTION=201.htmI
} 
The members of IADAA undertake not to purchase or sell objects until they have established to the best of their ability that such objects were not stolen from excavations, architectural monuments, public institutions or private property.

Antiquities collectors are largely dependent for advice about international laws and standards upon dealers and to a lesser extent museum or university experts. Dealers, at least, seem unlikely to be advising customers about the desirability of a Pre-UNESCO provenance, when they do not themselves acknowledge the legitimacy of a 1970 threshold. Faced with such an information shortfall, the majority of collectors are unlikely to recognize the normative significance or even existence of a 1970 threshold, and in those circumstances it is not surprising that it exerts no discernible effect on the market.

Mackenzie (2005) and Elia (2010) from their different disciplinary perspectives have written about the narrative 'discourses' or 'mythologies' that antiquities dealers and collectors use to justify their actions and neutralize any allegations of damage that their actions entail. The idea of market autoregulation seems on the basis of data examined here to be another example of a free-floating narrative not anchored to any empirical reality. It is hard, however, to discern the reasons for its genesis and persistence. The views of Souren Melikian have figured prominently in this paper, and to a certain extent that was a deliberate choice. Although Melikian reports upon the antiquities trade, he is not blind to its more problematical aspects, and has on occasion written critically about it (Melikian 2005). He might be considered a knowledgeable and non-partisan observer. In his hands, the idea of autoregulation looks more like an exercise in self-deceiving wish-fulfilment than it does an overtly mischievous attempt to discount the trade's harmful manifestations. It is perhaps for similar reasons that the idea of autoregulation appeals to a broad constituency. For dealers, it obviates the need for any further statutory regulation or normative restraint. For regulators, it suggests a successful mitigating influence of the 1970 UNESCO Convention. Whatever the reasons, the analyses presented in this paper highlight the dangers of accepting narrative accounts as fact without first subjecting them to rigorous empirical examination, particularly as regards public policy. For example, an argument that the legal regulation of the antiquities market in the United States is in need of reform was prompted in part by a belief that there has been a change in the normative context of antiquities collecting. This belief was nourished by an observation that 'the antiquities that have recently come to auction with secure provenance have fetched premiums', which noted as an authority Melikian's (2010) assertions about Pre-UNESCO provenance (Adler and Urice 2011: 122 note 27). Further research into the long-term relationships between object provenance, quality and price is ongoing, and in conjunction with the findings presented in this paper should provide a firmer empirical base for policy choice, design and assessment.

\section{Acknowledgements}

The research leading to these results has received funding from the European Research Council under the European Union's Seventh Framework Programme (FP7/2007-2013)/ERC Grant agreement no. 283873. The data and issues discussed were first presented in May 2013 at the Vulnerability and Cultural Heritage 
conference held at the University of Leicester, and thanks are due to Professor Janet Ulph for organising the conference and inviting the author to attend.

\section{Bibliography}

Adler, A.L. \& Urice (2011). Resolving the disjunction between cultural property policy and law: A call for reform. Rutgers Law Review, 64(1), 117-163.

Adler, M.A. \& Bruning S.B. eds. (2012). The Futures of our Pasts: Ethical Implications of Collecting Antiquities in the Twenty-first Century. Santa Fe: School for Advanced Research.

Akerlof, G.A. (1970). The market for 'lemons': Quality uncertainty and the market mechanism. Quarterly Journal of Economics, 84 (3), 488-500.

ATG (1999). Digging a little deeper to find early treasures. Antiques Trade Gazette, 6 November, 5.

Baugh, M. (2007). Antiquities: The hottest investment. Time, 12 December.

http://www.time.com/time/business/article/0,8599,1693792,00.html. Accessed 11 July 2013.

Blake, J. (1998). Illicit antiquities and international litigation: the Turkish experience. Antiquity, 72, 824-30.

Blumenthal, R. \& Mashberg, T. (2012). The curse of the outcast object. New York Times, 12 July.

http://www.nytimes.com/2012/07/15/arts/design/antiquity-market-grapples-with-stricter-guidelines-forgifts.html?pagewanted=all\& $r=0$. Accessed 11 July 2013.

Borodkin, L. (1995). The economics of antiquities looting and a proposed legal alternative. Columbia Law Review, 95, 377-417.

Braithwaite, J. (2002). Restorative Justice and Responsive Regulation. New York: Oxford University Press.

Brodie, N., Doole, J. \& Watson, P. (2000). Stealing History: The Illicit Trade in Cultural Material. Cambridge: McDonald Institute.

Brodie, N, Kersel, M.M., Luke, C. \& Tubb, K.W. eds. (2006). Archaeology, Cultural Heritage and the Antiquities Trade. Gainesville: University Press of Florida.

Cannon-Brookes, P. (1994) Antiquities in the market place: Placing a price on documentation. Antiquity, 68, 349-350. 
Chappell, D. \& Polk, K. (2011). Unraveling the "chordata": Just how organized is the international traffic in cultural objects? In S. Manacorda \& D. Chappell (Eds.), Crime in the Art and Antiquities World (pp. 99-116). New York: Springer.

Chippindale, C. \& Gill, D. (2000). Material consequences of contemporary classical collecting. American Journal of Archaeology 104(3): 463-511.

Christie's (2011). Antiquities, Including Property from the Collection of Baron Edouard Jean Empain, Thursday 14 April 2011. London: Christie's.

Elia, R.J. (2009). Mythology of the antiquities market. In J.A.R. Nafziger \& A.M. Nicgorski (Eds.), Cultural Heritage Issues: The Legacy of Conquest, Colonization, and Commerce (pp. 239-256). Leiden: Martinus Nijhof.

Forrest, C. (2010). International Law and the Protection of Cultural Heritage. London: Routledge.

Gay, M. (2012). For the St. Louis Art Museum, a legal victory raises ethical questions. Atlantic, 30 May. http://www.theatlantic.com/national/archive/2012/05/for-the-st-louis-art-museum-a-legal-victory-raisesethical-questions/257839/. Accessed 11 July 2013.

Gerstenblith, P. (2013). Has the market in antiquities changed in light of recent legal developments? In M.A. Adler and S.B. Bruning (Eds.), The Futures of Our Pasts: Ethical Implications of Collecting Antiquities in the Twenty-first Century (pp. 67-84). Santa Fe: School for Advanced Research.

Gill, D. (2013). Recently surfaced antiquities on the market.

http://lootingmatters.blogspot.co.uk/2013/06/recently-surfaced-antiquities-on-market.html. Accessed 11 July 2013.

Grimes, W. (2009). Jan Mitchell, who put the ü back in Lüchow's, dies at 96. New York Times, 30 November. http://www.nytimes.com/2009/12/01/nyregion/01mitchell.html. Accessed 11 July 2013.

Jones, J. (1985). The Art of Precolumbian Gold. The Jan Mitchell Collection. New York: Metropolitan Museum of Art.

Kaye, L. \& Main, C. (1995). The saga of the Lydian Hoard: from Uşak to New York and back again. In K.W. Tubb (Ed.), Antiquities: Trade or Betrayed (pp. 150-161). London Archetype.

Lazrus, P.K. \& A.W. Barker eds. (2012). All the King's Horses. Washington DC: Society for American Archaeology.

Mackenzie, S.R.M. (2005). Going, Going, Gone: Regulating the Market in Illicit Antiquities. Leicester: Institute of Art and law. 
Mackenzie, S.R.M. \& P. Green eds. (2009). Criminology and Archaeology. Oxford: Hart.

Manacorda, S. \& Chappell, D. eds. (2011). Crime in the Art and Antiquities World. New York: Springer.

Melikian, S. (1995). A degree of destruction unprecedented in the history of the world-and yet I support collecting. Art Newspaper, October (52), 27.

Melikian, S. (2008). A wake-up call for the antiquities market. New York Times, 12 June.

http://www.nytimes.com/2008/06/14/arts/14iht-melik14.1.13666041.html?pagewanted=all. Accessed 11 July 2011.

Melikian, S. (2010). Wanted: Antiquities beyond reproach. New York Times, 17 December.

http://www.nytimes.com/2010/12/18/arts/18iht-melik18.html?pagewanted=all. Accessed 11 July 2013.

Melikian, S. (2012). How UNESCO's 1970 Convention is weeding looted artifacts out of the antiquities market.

Blouin ArtInfo. http://www.blouinartinfo.com/news/story/822209/how-unescos-1970-convention-is-weedinglooted-artifacts-out-of-the-antiquities-market. Accessed 11 July 2013.

Melikian, S. (2013). Antiquities, with a proven record, drive auction market. New York Times, 14 June.

http://www.nytimes.com/2013/06/15/arts/15iht-melikian15.html?pagewanted=all. Accessed 11 July 2013.

Nafziger J.A.R. \& Nicgorski A.M. eds. (2009). Cultural Heritage Issues: The Legacy of Conquest, Colonization, and Commerce. Leiden: Martinus Nijhof.

Nørskov, V. (2002). Greek Vases in New Contexts. Aarhus: Aarhus University Press.

O'Keefe, P.J. 2000. Codes of ethics and the art trade. In F. Francioni, A. Del Vecchio \& P. De Caterini (Eds.), Protezione internazionale del patrimonio culturale: interessi nazionali e difesa del patrimonio comune della cultura (pp. 141-154). Rome: Giuffrè.

O'Keefe, P.J. (2007). Commentary on the 1970 UNESCO Convention. Leicester: Institute of Art and Law.

Prott, L. (2005). The international movement of cultural objects. International Journal of Cultural Property, 12, 225-248.

Prott, L. (2000). UNESCO celebrates thirtieth anniversary of its convention on illicit traffic. International Journal of Cultural Property, 9, 347-349.

Rhodes, R.F. ed. (2007). The Acquisition and Exhibition of Classical Antiquities. Notre Dame: University of Notre Dame Press. 
Rountree, C. (2008). The Geddes Collection. Bonhams Magazine, Autumn, 43.

Russell, H. (2004). Western antiques: the past year has seen a concerted effort by auction houses and dealers to put past troubles in the market behind them, and concentrate on well-provenanced objects of high quality.Apollo, 1 December.

http://www.thefreelibrary.com/Western+antiques\%3A+the+past+year+has+seen+a+concerted+effort+by...a0126194880. Accessed 11 July 2013.

Sotheby's (2010). Antiquities from the Collection of the Late Clarence Day. New York: Sotheby's.

Squires, N. (2008). Suspicions that Roman artefacts were illegally traded. Telegraph, 16 October.

Tijhuis, E. (2006). Transnational Crime and the Interface between Legal and Illegal Actors: The Case of the Illicit Art and Antiquities Trade. Nijmegen: Wolf Legal.

Tsirogiannis, C. (2013). Something is confidential in the state of Christie's. Journal of Art Crime Research, Spring, 3-20.

Watson, P. (1997). Sotheby's: Inside Story. London: Bloomsbury.

Watson, P. \& Todeschini, C. (2007).The Medici Conspiracy. New York: Public Affairs. 